ISSN : $2302-1590$

E-ISSN: $2460-190 \mathrm{X}$

ECONOMICA

Journal of Economic and Economic Education Vol.4 No.2 (269-287)

\title{
ANALISIS PEMASARAN DAN KEBIJAKAN PERDAGANGAN INTERNASIONAL DI SUMATERA BARAT
}

\author{
Yolamalinda ${ }^{1}$ Hayu Yolanda Utami ${ }^{2}$ Dina Amaluis ${ }^{3}$ \\ Dosen Program Studi Pendidikan Ekonomi STKIP- PGRI Sumbar \\ Jl. Gunung Pangilun No.1, Padang Sumatera Barat \\ ${ }^{1}$ Email: yolamalinda@gmail.com \\ submited: 2016.06.21 reviewed: 2016.07.01 accepted: 2016.07.01 \\ http://dx.doi.org/10.22202/economica.2016.v4.i2.632
}

\begin{abstract}
Globalization and free tradeer bring opportunities to companies to enter world market and at the same time demand companies and other actors eagerness to compete in world market. International trade theories proven only explain minor private business behavior which is associated with international trade. This article analyze West Sumatra Export performance by using export model which majoring focus on internal and external factors companies as private business. Result shows internal factors companies which are associated with marketing strategy, including product adaptation, market segmentation, world market, price adaptation, local and international channel relationship and export planning, and also that are associated with manager behavior to consumer and competitor have positive effect to export performance. The same result also indicated by external factors have positive effect to export performance. Unstable economic condition evident by fluctuation of rupiah toUS dollar required companies to have another strategy tobe able tocompete in world market. One of the srategy is strength internal factors as controllable factor therefore will give value added to its product to compete with other countries.
\end{abstract}

\section{Abstrak}

Globalisasi dan era perdagangan bebas memberikan kesempatan kepada perusahaan ekspor untuk masuk kedalam pasar dunia sekaligus juga menuntut kesiapan perusahaan dan aktor pendukung lainnya untuk bersaing. Teori-teori perdagangan internasional selama ini terbukti hanya menjelaskansedikit saja dari perilaku bisnis pribadi yang berhubungan dengan perdagangan internasional. Artikel ini menganalisis kinerja ekspor Sumatera Barat dengan menggunakan model perkembanganekspor yang mengutamakan faktor internal dan eksternal perusahaan sebagai unit usaha pribadi. Hasil menunjukkan bahwa faktor internal perusahaan yang berkaitan dengan strategi pemasaran ekspor seperti adaptasi produk, segmentasi pasar,pasar dunia, adaptasi harga,hubungan dalam danluar negeri dan juga perencanaan ekspor dan yang berkaitan dengan perilaku managerial terhadap konsumen dan kompetitor menunjukkan hubungan dan pengaruh yang positif terhadap kinerjaekspor. Begitu juga dengan faktor eksternal perusahaan yang mencakup hambatan ekspor dan regulasi menunjukkan hubungan dan pengaruh yang positif terhadap kinerja ekspor. Kondisi perekonomian yang tidak stabil ditandai dengan berfluktuasinya nilai rupiah terhadap Dollarmembutuhkan strategi lain untuk terus dapat bersaing dengan produk luar negeri. Salah satunya dengan memperkuat sektor internal sebagai factor yang dapat dikontrol perusahaan sehingga dapatmemberikan nilai tambah bagi suatu produk itu untuk bersaing dengan negara lain

Keywords: exportperformance, internal factors, external factors, international trade 


\section{PENDAHULUAN}

Indonesia merupakan sebuah negara dengan perekonomian terbuka yang mengandalkan perdagangan luar negeri untuk menunjang perekonomiannya. Ekspor memberikan sumbangan devisa yang cukup besar untuk membiayai pembangunan. Yang paling besar memberikan kontribusi bagi neraca perdagangan Indonesia adalah ekspor non migas setelah menggeser posisi ekspor migas yang terus menurun setelah terjadinya resesi dunia.

Dengan melakukan ekspor dipercaya suatu negara akan dapat meningkatkan standar kehidupan. Seperti yang dikemukakan para ekonom dalam teori-teorinya, antara lain teori Merkantilisme (sekitar abad 16 dan 17), teori Keunggulan Absolut (Adam Smith 1776), Teori Keuntungan Komperatif (David Ricardo 1817), Factor Endowment (Eli Heckscher dan Bertil Ohlin, 1990-an), dan Teori Product Life Cycle (Vernon 1966, Wells 1968). Semua teori ini mengemukakan keuntungankeuntungan yang dapat diperoleh dengan melakukan perdagangan internasional.

Namun, sayangnya semua teori ini hanya menjelaskan sebagian saja perilaku bisnis pribadi yang berhubungan dengan perdagangan internasional. Maka dari itu muncul model-model perkembangan ekspor yang tidak hanya melihat dari segi rasional ekonomi seperti pada teori-teori murni perdagangan internasional, namun juga melihat segi perilaku perusahaan melalui keterlibatannya dalam ekspor (Leonidou 1996).

Perkembangan model-model ekspor ini mengutamakan pada faktor internal dari perusahaan yang diyakini memiliki efek yang lebih kuat daripada faktor ekstenal. Seperti yang dikemukakan oleh Gomez (1988) melalui studinya yang dilakukan di Amerika Serikat bahwa untuk meningkatkan ekspor dibutuhkan manajemen sumberdaya manusia yang bagus. Aspirasi dan persepsi manajerial disini memiliki kontribusi yang tinggi bagi kinerja perusahaan yang berorientasi ekspor.

Aspirasi dan persepsi seorang manajer akan membawa perusahaan untuk meningkatkan keuntungan dan perluasan pasar melalui strateginya terhadap perencanaan dan tujuan masa depan. Cooper mengukur kinerja ekspor dengan memasukkan variabel strategi dalam penelitiannya. Strategi tersebut dapat berupa desain produk, pemilihan negara tujuan ekspor maupun segmentasi pasar. Osman Muhammad (2001) juga menambahkan strategi harga, strategi pemasaran, dan strategi distribusi dalam penelitiannya.

Untuk membantu manajer merubah strateginya setiap saat diperlukan sebuah ukuran orientasi pasar ekspor yang berpatokan pada konsumen, kompetitor dan pengaruh pasar eksogen. Dengan menerapkan orientasi pasar pada perusahaan akan memberikan dampak positif bagi perusahaan yang ditandai tingkat keuntungan, volume penjualan, kualitas produk dan pangsa pasar (Cadogan 1999).

Saat ini Indonesia umumnya dan Sumatera Barat khususnya harus menghadapi tingkat persaingan yang cukup tinggi dari negara lain sebagai akibat diberlakukannya Kawasan Perdagangan Bebas ASEAN (AFTA) pada tahun 2003. Hal ini menuntut kesiapan para pelaku ekonomi tidak terkecuali perusahaan sebagai unit bisnis pribadi yang berorientasi pasar ekspor. Karena dengan berlakunya AFTA berarti dihapusnya hambatan bagi masuknya barang dan jasa ke dalam negeri.

Sumatera Barat merupakan salah satu propinsi di Indonesia yang mengandalkan sektor pertanian sebagai komoditi ekspor utamanya, di samping sektor pertambangan dan sektor industri pengolahan. Sektor pertanian memiliki keterkaitan dengan sektor industri pengolahan yang memiliki orientasi pasar ekspor, dimana sektor pertanian merupakan bahan baku utama bagi sektor 
industri. Keterkaitan kedua sektor ini menjadi landasan kebijakan ekonomi pembangunan daerah. Begitu juga halnya dengan orientasi pasar, apakah itu pasar lokal, pasar antar daerah, maupun pasar luar negeri. Kebijakan pembangunan ekonomi Sumatera Barat harus dapat mengisi peluang pasar yang tercipta di luar negeri (Karimi 2002).

Rentannya kinerja ekspor terhadap dampak krisis global juga tidak terlepas dari karakteristik ekspor Sumatera Barat selama ini. Kurang terdiversifikasinya negara tujuan ekspor, menyebabkan kinerja ekspor Sumatera Barat langsung mendapat pukulan berat. Selain itu, komoditas ekspor Sumatera Barat juga cenderung kurang terdiversifikasi di mana komoditas utama ekspor sebagian besar masih berbasis sumber daya alam yang ternyata justru sangat rentan terhadap gejolak harga. Melemahnya kinerja ekspor ini selanjutnya memberikan tekanan pada sektor-sektor lainnya yang memasok bahan baku pada sektor industri ekspor.

Penelitian yang dilakukan Sjamsul Arifin menemukan bahwa nilai tukar hanya memiliki dampak kecil bagi pertumbuhan ekspor. Dengan mendepresiasi Rupiah sebesar 1\% hanya dapat meningkatkan ekspor sebesar 0,08 $\%$. Jadi tidak ada alasan bagi dunia usaha yang merasa terancam dengan adanya apresiasi nilai tukar. Karena ada faktorfaktor lain yang dapat mempengaruhi ekspor, salah satunya adalah faktor internal dan faktor ekaternal perusahaan itu sendiri.

Kebijakan pemerintah yang memfokuskan pada kebijakan nilai tukar hanya memilki pengaruh yang sedikit bagi kinerja ekspor Sumatera Barat. Dalam model-model perkembangan ekspor, faktor internal perusahaan memiliki peranan utama dibandingkan faktor eksternal perusahaan. Dimana dalam faktor internal termasuk persepsi manajerial dalam merencanakan masa depan. Seorang manajer yang beorientasi pasar ekspor terbukti mampu meningkatkan kinerja ekspor perusahaannya (Cadogan 1999).
Sumatera Barat merupakan Propinsi yang mengandalkan sektor primer sebagai sektor untuk memacu pertumbuhan ekonominya. Namun nyatanya sektor pertanian terus mengalami penurunan nilai ekspornya. Fluktuasi harga komoditi yang disebabkan oleh krisis ekonomi Asia menandakan bahwa perekonomian Sumatera Barat tidak terlepas dari faktor eksternal.

Sumatera Barat menerapkan strategi berorientasi keluar yang menekankan pada produksi barang dan jasa yang diarahkan untuk memenuhi pasar luar negeri. Strategi ini dimaksudkan untuk meningkatkan daya saing produk lokal, menambah pangsa pasar produk lokal. Pada periode 19832012 terbukti bahwa perdagangan dengan menerapkan strategi ini dapat mendorong pertumbuhan ekonomi Sumatera barat yakni sebesar $13,04 \%$ pertahun, rata-rata laju pertumbuhan ekspor sebesar $5,41 \%$ pertahun.

Komoditas-komoditas andalan Sumatera Barat saat ini harus menghadapi persaingan dengan komoditi yang sama dari daerah lain dalam merebut pangsa pasar ekspor. Penurunan yang dialami terlihat dalam kontribusinya terhadap perekonomian Sumatera Barat sebesar $13,57 \%$ pada periode 1983-2012. Penurunan ini menandakan lambannya perkembangan produk yang berorientasi ekspor.

Penurunan jumlah ekspor ini tidak terlepas dari kondisi perekonomian Indonesia yang memburuk akibat krisis keuangan global. Kondisi perekonomian Indonesia saat ini memang masih tidak stabil, ditandai dengan terus berfluktuasinya nilai Rupiah terhadap Dollar Amerika Serikat. Untuk terus dapat bersaing dengan produk luar negeri, dunia usaha, khususnya di Sumatera Barat hendaknya memiliki strategi khusus. Salah satunya dengan memperkuat sektor internal yang akan memberikan nilai tambah bagi suatu produk itu untuk bersaing dengan poduk lain. 
Seorang eksportir yang memiliki orientasi pasar ekspor dapat meningkatkan profit, volume penjualan, kualitas produk, dan pangsa pasar sehingga bisa bersaing secara mutu di pasar internasional. Orientasi pasar ekspor berpatokan pada konsumen, kompetitor, dan pasar eksogen, karena dengan mengetahui selera konsumen, merespon setiap strategi yang dilakukan kompetitor, dan memperhitungkan pasar eksogen maka kinerja ekspor suatu perusahaan akan meningkat. Dengan mengukur orientasi pasar ekspor yang dilakukannya, seorang eksportir dapat mengetahui kelemahankelemahan dari sisi internal dan eksternal yang perlu diperbaiki. Untuk itu penulis ingin mengetahui bagaimana pengaruh faktor eksternal dan internal perusahaan bagi kinerja ekspor Sumatera Barat.

\section{METODE PENELITIAN}

Pada tahap awal, peneliti mengadakan observasi (Grand Tour) ke lokasi penelitian. Kemudian melakukan wawancara ke pihak pimpinan perusahaan ekspor terkait faktor internal dan eksternal perusahaan. Serta wawancara ke Dinas Perindustrian dan Perdagangan Provinsi Sumatera Barat terkait kebijakan perdagangan internasional.

Penelitian ini dilaksanakan di 34 perusahaan ekspor di Sumatera Barat yang seluruhnya tersebar di Kota Padang.

Populasi dari penelitian ini adalah seluruh perusahaan ekspor barang primer yang ada di Sumatera Barat yang berjumlah 34 perusahaan. Oleh karena itu teknik pengambilan sampel adalah total sampling dimana seluruh perusahaan ekspor dijadikan sampel.

Untuk menjelaskan pengaruh variabel internal dan eksternal perusahaan digunakan analisis chi square dengan menggunakan analisis pearson chi square dengan ketentuan sebagai berikut:
1. Chi square $\geq$ chi square tabel, terdapat pengaruh

2. Chi square < chi square tabel, tidak ada pengaruh

\section{Literature Review}

\section{A. Perkembangan Model Ekspor}

Perkembangan ekspor dijunjung tinggi oleh para pembuat kebijakan bersama dan publik, terutama yang berpengaruh pada ekonomi mikro dan makro yang didapat dari perdagangan eksternal. Dari sisi ekonomi makro, ekspor memungkinkan ekonomi nasional untuk memperkaya cadangan nilai tukar asingnya, tenaga kerja, menciptakan hubungan backward dan forward, dan membawa pada standar kehidupan yang lebih tinggi (Czinkota, Rivoli, dan Ronkainen (1992) dalam Leonidou dan Constantine S (1996)). Pada sisi ekonomi mikro, ekspor dapat memberikan keuntungan kompetitif bagi perusahaan pribadi, meningkatkan posisi keuangan dan kapasitas mereka, serta meningkatkan standar tekhnologi (Terpstra dan Sarathy, 1994 dalam Leonidas dan Constantine S, 1996).

Seperti yang dikutip oleh Leonidou dan Constantine $\mathrm{S}$, dengan adanya keuntungan ini, para ekonom memberikan kontribusi berupa teori-teori dalam perdagangan internasional. Yang paling terkenal adalah teori keuntungan absolut (Smith 1776), keuntungan komperatif (Ricardo 1817), faktor endowment (Ohlin 1993; Hekscher 1950), dan product life cycle (Vernon 1966; Wells 1968). Meskipun teori ini berguna dalam menganalisis dengan perdagangan internasional, model-model ini hanya menjelaskan sebagian saja dari perilaku ekspor dari unit bisnis pribadi (Wells 1968; Bilkey 1978; Cannon 1980, dalam Leonidas dan Constantine S).

Karena terbatasnya ruang lingkup dari teori ekonomi, banyak peneliti yang mengadopsi pendekatan yang lebih mikroskopik. Studi mereka menghasilkan 
berbagai model dimana perusahaan pribadi menuntun, berkembang, dan menopang ketelibatannya dalam ekspor (Haar dan Ortiz-Buonafina, 1995 dalam Leonidas dan Constantine S, 1996). Model-model ini tidak hanya berfokus pada rasional ekonomi dari proses perkembangan ekspor, seperti pada teori perdagangan internasional, namun juga dikonsetrasikan pada perilaku dari perusahaan yang berhubungan dengan perdagangan (Albaum, Strandskov Duern dan Dowl 1994 dalam Leonidas dan Constantine S 1996).

Berikut ini adalah para peneliti yang telah mencoba mengembangkan model-model ekspor :

\section{Johansen dan Wiedersheim-Paul (1975)}

Mengungkapkan suatu model yang menekankan pada bentuk organisasi atas keterlibatan suatu negara dalam bisnis internasional. Ditemukan bahwa konsep kunci dari perkembangan model ekspor adalah jarak fisik, ditentukan sebagai ratarata faktor dari gangguan informasi antara perusahaan dan pasar asing. Berdasarkan konsep ini perusahaan lebih memilih negara dengan psikologi tertutup, dengan resiko yang lebih rendah.

\section{Bilkey dan Tesar (1977)}

Mengungkapkan

proses

pengembangan ekspor dari perspektif peningkatan ketergantungan perusahaan berdasarkan jarak suatu negara secara psikologis. Uji empiris model ini menyatakan bahwa aktivitas ekspor dapat ditinjau sebagai proses pembelajaran, dimana perusahaan secara berangsurangsur menjadi familiar dengan operasi dan pasar internasional. Kualitas manajemen, dinamisme yang diekspresikan oleh kemampuan teknis, kemampuan bisnis dan orientasi perencanaan yang terpenting untuk memajukan ekspor.

\section{Wiedersheim-Paul, Olson dan Welch} (1978)

Pada tahap pre-engagement, proses ekspansi perusahaan membutuhkan fokus terhadap investigasi terhadap model ini.
Berdasarkan keinginan perusahaan untuk melakukan ekspor dan kemampuan perusahaan untuk mengumpulkan informasi.

\section{Wortzel dan Wortzel (1981)}

Dalam melakukan penelitiannya langkah-langkah dibedakan atas derajat pengawasan yang diterapkan oleh eksportir dalam operasi internasional yang akan didukung oleh produksi dalam negeri, marketing, dan fungsi yang sebelumnya dibentuk oleh konsumen asing. Model ini menyatakan pentingnya pendekatan kontingensi dalam identifikasi dan seleksi strategi optimum atas keterlibatan perusahaan dalam aktivitas pasar internasional.

\section{Cavusgil (1982)}

Proses pengembangan ekspor disusun untuk mendapatkan suatu keputusan yang baik melalui manajemen selama periode tertentu, yang berpedoman terhadap konsep perilaku ekspor. Perkembangan ekspor didapatkan sebagai hasil dari keputusan manajer. Model ini menempatkan faktor perusahaan dan manajerial sebagai penunjang atau penghalang bagi kemampuan perusahaan.

\section{Czinkota (1982)}

Mengembangkan suatu model yang bertujuan untuk mendeteksi perbedaan antara beberapa tipe dari beberapa tipe perusahaan manufaktur dengan menggunakan asistensi pengambilan ekspor pemerintah. Hasil empiris dari penelitian ini adalah bahwa perusahaan memiliki pertimbangan yang berbeda dalam aspek organisasi, manajerial dan karakteristik internal perusahaan.

\section{Barett dan Wilkonson (1986)}

Menyatakan suatu model yang berfokus pada tingkatan keterlibatan ekspor dari perusahaan. Model ini menunjukkan tingkat signifikasi yang berbeda antara perusahaan dalam level yang berbeda berdasarkan top manajemen, seperti karakteristik personal, orientasi perencanaan aktivitas luar negeri, dan tingkah laku dalam bisnis internasional. 
Moon dan Lee (1990)

Berusaha menjelaskan proses ekspor yang dinamis dengan menciptakan beberapa variabel independen. Berdasarkan penelitian ada tiga perbedaan level dari ekspansi ekspor menjadi tahap lower, middle, dan higher.

\section{Rao dan Naidu (1992)}

$$
\text { Memiliki empat kategori }
$$

perusahaan berdasarkan tingkat aktivitas ekspor mereka, non exporters, export interders, sporadic exporters, dan regular exporters.

\section{Recently, Crick (1995)}

Menawarkan

konsep

internasionalisasi perusahaan yang melakukan ekspor berdasarkan kriteria dari Bilkey dan Tesar (1977) dan Czinkota (1982). Dia mengkategorikan perusahaan kepada tiga tipe, yaitu : non-eksportir, pasif eksportir, dan aktif eksportir.

Dari berbagai model dapat dikatakan bahwa dalam proses pengembangan ekspor dapat dibagi kedalam tiga fase utama:

\section{- Pre engagement}

Terdapat tiga macam perusahaan: semata-mata menjual produknya untuk pasar domestik dan tidak tertarik untuk mengekspor, terlibat dalam pasar domestik tetapi ada keinginan untuk melakukan kegiatan ekspor, dan melakukan ekspor namun dalam waktu yang tidak terlalu lama

\section{- Initial Phase}

Perusahaan terlibat dalam aktivitas ekspor yang sporadik dan mempertimbangkan berbagai pilihan. Disini perusahaan dapat diklasifikasikan atas potensinya dalam keterlibatan internasional.

\section{- Advanced Phase}

Perusahaan adalah regular eksportir dengan pengalaman dan secara bertahap melakukan bisnis internasional.

Perdagangan internasional memberikan peluang dan kesempatan kepada setiap negara untuk meningkatkan taraf perekonomiannya. Untuk itu maka setiap negara akan berusaha untuk meningkatkan eskpornya. Dimana peningkatan ekspor ini sangat terkait dengan pada kualitas produk, strategi pemasaran, ataupun campur tangan pemerintah. Berhasil atau tidaknya suatu perusahaan ditentukan oleh kinerja ekspornya masing-masing. Kinerja ekspor ditentukan oleh faktor eksternal dan internal. Dimana sosial budaya, lingkungan, politik, serta kondisi pasar dalam dan luar negeri merupakan faktor eksternal, sedangkan manajerial dan karakteristik perusahaan merupakan faktor internal.

\section{B. Faktor Internal}

Greenberg (1986) dalam Gomez (1988) menegaskan bahwa variabel internal dapat dikategorikan :

1. Perbedaan Keunggulan Perusahaan

Perusahaan akan cenderung meningkatkan ekspornya jika perusahaan semakin besar. Ukuran perusahaan akan mempengaruhi alokasi sumberdaya, kapasitas produksi dan skala ekonomi. Perusahaan tersebut akan bersedia mengadaptasi produk teknologi, memperbesar pengeluaran $\mathrm{R} \& \mathrm{D}$, meningkatkan perluasan produksi utama, manajemen lebih bersifat internasional.

Keunggulan perusahaan tersebut dapat dibagi menjadi (Muhammad, 2001): keunggulan pemasaran, keunggulan produk, keunggulan manajemen, keunggulan distribusi, keunggulan promosi. Keunggulan yang dimiliki oleh perusahaan ini merupakan faktor penentu bagi prestasi perusahaan.

2. Aspirasi dan Persepsi Manajerial Variabel ini menggambarkan pendekatan sosiologi bagi top manajemen yang terdiri dari :

- Persepsi resiko, ditemukan oleh Kujawa dan Simpson dalam Schlegelmeilch (1988) bahwa perusahaan ekspor tidak terlalu cemas terhadap resiko dibandingkan dengan perusahaan non ekspor. 
- Perluasan Peningkatan Pandangan Internasional, Teori ini mengatakan bahwa perusahaan akan mengekspor bermula pada negara-negara yang secara psikologi tertutup. Hal ini didukung oleh studi yang dilakukan di Amerika Serikat dimana perusahaan dengan intensitas rendah akan cenderung mengekspor pada negara tetangganya (Kanada). Kemudian setelah nilai penjualan tinggi akan memperluas wilayah ekspornya ke negara-negara lain.

- Pengaruh Pemasaran, Cooper dalam Schlegelmeich menemukan bahwa penjualan dengan orientasi penjualan berhubungan dengan intensitas ekspor yang sangat tinggi.

3. Pendekatan Perusahaan untuk Pasar Luar Negeri, Setiap negara yang ekonominya tergantung kepada perdagangan luar negeri akan memperluas peluang ekspor mereka dengan berorientasi internasional. Meskipun pada awalnya kebanyakan perusahaan kecil dan menengah akan memfokuskan pada pasar domestik. Untuk meningkatkan perekonomian suatu negara maka banyak negara melakukan strategi promosi ekspor. Sehingga mengharuskan perusahaan untuk berorientasi secara internasional (Dichtl, dkk, 1990).

Penelitian-penelitian

yang

dilakukan sebelumnya menyatakan bahwa orientasi pasar cukup besar pengaruhnya pada organisasi, produk baru, kualitas produk, pelayanan konsumen, sales-force commitment, hubungan, ROA, keuntungan, volume penjualan, pertumbuhan dan pangsa pasar. Untuk menggeser orientasi perusahaan dari domestik ke internasional juga diperlukan pengukuran dari pasar domestik yang berpatokan pada konsumen, kompetitor, dan juga pasar eksternal.

Untuk

melakukan internasionalisasi dibutuhkan orang yang tepat pada tempat yang tepat (right man on the right place). Dimana orang tersebut harus melebihi kemapuan tradisional dan diakui secara internasional. Persoalanpersoalan yang ditemui dalam melakukan orientasi internasional :

- Kemampuan berbahasa dan kemampuan personil

- Persoalan wilayah yang berpengaruh pada distribusi dan investasi

- Riset dan pelayanan informasi pemerintah harus menekankan untuk meningkatkan pengetahuan bagi pentingnya ekspor

Gomez (1988) menekankan bahwa manajemen sumberdaya manusia (SDM) merupakan strategi yang amat penting untuk meningkatkan ekspor, seperti yang dicatat oleh Departemen Perdagangan AS, hambatan yang dialami negaranya dalam mengembangkan ekspor adalah karena kurangnya pengetahuan tentang pasar luar negeri, praktek bisnis, dan kompetisi, kurangnya komitmen manajemen untuk menggerakkan penjualan di luar negeri. Hambatan ini diartikan sebagai akibat kurangnya penggunaan SDM, yang dapat diatasi dengan menggunakan SDM yang berorientasi internasional.

Cooper dan Elko menambahkan dalam penelitiannya dimasukkan variabel strategi sebagai salah satu variabel yang mempengaruhi kinerja ekspor. Dimana strategi tersebut dapat diklasifikasikan kedalam tiga dimensi :

1. Strategi adaptasi (adaptasi vs nonadaptasi)

Yakni strategi yang menyesuaikan desain produk dengan selera atau permintaan spesifik dari pasar luar negeri.

2. Strategi segmentasi (single segment vs multi segment)

Yakni strategi untuk menentukan segmentasi pasar atas barang-barang ekspor, apakah satu atau multi segment.

3. Strategi orientasi (world vs nearest neighbour)

Yakni strategi pemilihan negara tujuan ekspor, pilihan biasanya ada dua, yakni negara-negara terdekat dan negara lain (world). 
Lee dan John J. (1978) mengungkapkan bahwa penggunaan strategi ekspor merupakan sebuah keputusan yang sulit. Dapat dilihat dari banyaknya perusahaan yang melakukan ekspor tidak selalu intelektual dalam proses membuat keputusan ekspor. Sehingga selalu menjadi pertanyaan apakah sebuah perusahaan rasional atau tidak dalam membuat keputusan ekspor. Sebuah inovasi dalam proses keputusan yang dibuat dalam melakukan adopsi bisa rasional dan bisa tidak rasional.

Proses adopsi dikatakan oleh Johansen-Vahine merupakan proses yang mendasari perusahaan dalam melakukan ekspor. Berikut adalah alternatif proses adopsi yang digunakan:

1. Problem Oriented Adoption Process (POAP), adalah sebuah kekuatan yang mendasari perusahaan untuk melakukan adoption process oleh satu atau kombinasi permasalahan yang saling berhubungan, seperti produk akhir, meningkatnya kompetisi dalam negeri, menurunnya penjualan dan keuntungan, keinginan untuk melakukan perluasan pasar.

2. Innovation Oriented Adoption Process $(I O A P)$, adalah adoption process yang didasari salah satunya oleh pengetahuan tentang adanya kesempatan pasar untuk produk dan merek dalam negeri.

3. Rational Adoption Process (RAP), dalam mengambil keputusan adoption process menggunakan berbagai jenis dan sumber informasi, menggunakan dan menilai perencanaan dan pertimbangan.

4. Nonrational Adoption Process, dalam mengambil keputusan adoption process menggunakan sedikit kewenangan dan sumber informasi.

Berdasarkan penelitian yang dilakukan, Lee menemukan bahwa perusahaan melakukan proses absorpsi berdasarkan adanya kesempatan mereka untuk memasarkan produk mereka di luar negeri, namun dalam melakukannya kurang berdasarkan informasi dan pertimbangan.

\section{Faktor eksternal}

Faktor eksternal mencakup aspek sosial budaya, politik, lingkungan serta kondisi pasar dalam dan luar negeri. Faktor lingkungan merupakan faktor yang paling sulit dikendalikan perusahaan karena berada di luar perusahaan. Di antara faktor lingkungan ini adalah selera, bahasa, agama, serta undang-undang yang berlaku di negara tujuan ekspor.

\section{- Lingkungan}

Lingkungan perusahaan juga merupakan faktor yang penting bagi sebuah perusahaan dalam melakukan ekspor, selain dari karakteristik, pengambil keputusan, perluasan kawasan perusahaan dan informasi.

Lokasi perusahaan dalam pasar domestik adalah penting dihubungkan pada biaya transpor barang-barang fisik dan arus informasi. Hal ini akan memberikan efisiensi tinggi dalam wilayah urban, yang terdapat sejumlah besar perusahaan dan tempat-tempat kerja yang terpusat pada area kecil, meningkatkan kondisi untuk produksi dan menciptakan kelebihan lingkungan usaha.

\section{- Undang-undang}

Undang-undang yang berlaku pada suatu negara dapat menjadi penghalang bagi perdagangan internasional.

Misalnya saja kebijakan tariff yang dilakukan akan menaikkan harga jual dari suatu produk, sehingga akan mempersulit daya saingnya dengan produk lain.

Kebijakan perdagangan yang dilakukan negara berkembang menimbulkan kerimpangan. Seperti yang dikritik oleh Bank Dunia dan IMF bahwa kebijakan institusi (termasuk liberalisasi perdagangan) telah menimbulkan ketimpangan pada negara berkembang. Dimana indikator keberhasilan pada negara-negara berkembang adalah tariff rata-rata, average coverage dari restriksi kuantitatif, premi black market, rasio tariff gabungan. 
Kebijakan intervensi pemerintah yang dilakukan oleh pemerintah Korea mendorong pembangunan ekonomi menggunakan kebijakan industri promosi ekspor. Kebijakan ini tidak selalu berhasil dalam meningkatkan kesejahteraan rakyat. Hal ini disebabkan karena adanya perbedaan politik pada suatu negara (Westphdal, 1990).

Insentif yang diberikan pemerintah untuk mengembangkan ekspor dilakukan oleh hampir stiap negara yang untuk menumbuhkan perekonomiannya berorientasi ekspor. Dari beberapa studi yang dilakukan ditemukan hubungan yang positif antara insentif ekspor dan perilaku ekspor.

Penelitian yang dilakukan di Turki menunjukkan bahwa para pembuat keputusan menunjukkan ketertarikan terhadap insentif yang diberikan pemerintah. Para manajer menyadari perlunya insentif ekspor mendorong kesiagaan mereka terhadap perubahan lingkungan. Insentif yang diberikan adalah dalam hal bantuan teknis seperti promosi produk pada pasar luar negeri, bantuan impor bahan mentah dan asuransi ekspor.

Kasus perusahaan kecil dan menengah di Kanada, untuk memasuki pasar asing dibantu dengan cara EDC (Export Development Corporation), yaitu suatu lembaga yang menghasilkan eksportir-eksportir Kanada dengan memberikan bantuan keuangan berupa perjanjian kredit perdagangan dan juga asuransi. Secara umum tujuan EDC ini adalah untuk mempromosikan ekspor dengan jalan meningkatkan dukungan terhadap perusahaan kecil dan menengah yang ada di Kanada.

Salah satu kegagalan pasar yang ditemukan di Kanada adalah dalam hal jasa keuangan dan asuransi di pengaruhi oleh distorsi ekonomi yang timbul apabila pada saat melakukan transaksi kedua pihak mempunyai informasi yang berbeda mengenai nilai barang dan jasa yang akan ditukar.

\section{Orientasi Pasar Ekspor}

Perusahaan yang melakukan kegiatan bisnis menempatkan kepuasan konsumen sebagai sasaran utamanya. Seperti yang ditulis oleh Adam Smith pada tahun 1970-an yang dikenal dengan konsep marketing. Selama beberapa dekade terakhir ini, konsep marketing hanya berupa sebuah artikel belaka, bukannya sebuah landasan untuk membangun sebuah bisnis. Hal inilah yang menyebabkan akademisi mengembangkan konsep "orientasi pasar", untuk menggantikan konsep marketing yang telah dilupakan orang.

Beberapa peneliti yang menekankan bahwa konsumen merupakan fokus utama bagi sebuah orientasi pasar diantaranya seperti yang dikutip oleh Heiens (2000) adalah Deshpande dan Webster (1989), Payne (1988). Peneliti lainnya membangun orientasi pasar dengan menambahkan faktor-faktor eksogen yang dapat mempengaruhi kebutuhan konsumen, seperti kompetitor dan regulasi pemerintah. Sedangkan peneliti lainnya menambahkan, bila orientasi pasar tersebut berskala ekspor dan berhubungan dengan kinerja ekspor, selain konsumen, seorang eksportir juga harus memperhatikan faktor lingkungan ekspor dan meknisme koordinasi dalam perusahaan (Cadogan, 1999).

Informasi mengenai lingkungan eksternal merupakan hal yang paling penting bagi seorang manajer untuk membuat keputusan. Lingkungan eksternal tersebut meliputi konsumen dan kompetitor. Dalam penelitiannya Heiens (2000) menyebutkan bahwa Day dan Wensley (1988) menambahkan karakteristik konsumen dan kekuatan kompetitor memberikan efek terhadap aktifitas inteligensia.

Mengacu pada pendapat Slater dan Narver, saat pasar terpecah dan daya beli turun sangat penting untuk menitikberatkan pada kebutuhan konsumen. Pada saat ini kebutuhan konsumen susah untuk dipahami, dengan 
lebih berfokus kepada konsumen akan memberikan dampak yang besar bagi kinerja perusahaan. Selain karena faktorfaktor tersebut di atas, faktor lainnya yang menyebabkan pentingnya untuk menitikberatkan kepada konsumen adalah adanya pasar yang dinamis dengan hambatan yang berubah, terdapat banyak kompetitor, dan persaingan ketat di pasar. "lebih fokus kepada konsumen akan meningkatkan market share pada pasar yang berkembang"

Fokus kepada kompetitor adalah bagaimana cara perusahaan untuk mengidentifikasi kekuatan dan kelemahan lawan dan bagaimana menyikapinya agar tetap bertahan. Mengacu pada Day dan Wensley, saat permintaan pasar dapat diprediksi, struktur kompetisi stabil, dengan adanya beberapa kompetitor yang tangguh, maka perusahaan harus menitikberatkan kepada kompetitor. Semakin sedikit derajat serangan dari kompetitor akan memberikan dampak positif bagi kinerja."fokus kepada kompetitor akan meningkatkan market sare pada pasar yang stabil dan dapat diprediksi"

Sementara itu Slater dan Narver menyarankan untuk menyeimbangkan antara konsumen dan kompetitor. Perusahaan harus dapat menggeser sumberdaya antara konsumen dan kompetitor pada kondisi pasar yang berubah-ubah pada jangka pendek. Namun biaya untuk memonitor konsumen dan kompetitor sangat tinggi, sehingga perusahaan harus mengorbankan sebagian ROI untuk market share.

$$
\text { Cadogan (1999) selain }
$$

menekankan bahwa konsumen dan kompetitor memberikan pengaruh dalam pasar (pasar ekspor khususnya), ia juga menambahkan adanya pasar eksogen dan mekanisme koordinasi yang merupakan komponen perilaku yang meliputi respon kepada pasar ekspor dan orientasi terhadap konsumen ekspor.

Variabel-variabel yang digunakan Cadogan antara lain adalah: Export intelligence generation, export intelligence dissemination, export intelligence responsiveness, coordinating mechanism.

1. Export Intelligence Generation, meliputi seluruh aktifitas untuk menciptakan tingkat kecerdasan terhadap pasar ekspor, aktifitas tersebut meliputi penelitian terhadap pasar ekspor.

2. Export Intelligence Dissemination, meliputi seluruh aktifitas yang terlbat dalam penyebaran kepada karyawan dari aktifitas variabel pertama di atas.

3. Export Intelligence Responsiveness, mencakup rencana dan implementasi dari seluruh respon dari variabel pertama di atas.

4. Coordinating Mechanism, meliputi komunikasi, saling pengertian, organisasi yang berlandaskan tanggungjawab, kerjasama, dan saling membantu.

Penelitian yang digunakan Cadogan dapat digunakan untuk mengukur kinerja ekspor suatu perusahaan. Cadogan mengadakan penelitiannya dengan menggunakan sampel perusahaan manufaktur di negara Inggeris dan Belanda dengan menguji item-item yang digunakan untuk mengukur orientasi pasar ekspor. Pengujian ini menggunakan metode cross-cultural validation. Hasil yang didapatkan, bahwa ukuran orientasi pasar ekspor cukup valid untuk menguji kinerja ekspor suatu perusahaan.

Penelitian yang juga mengenai orientasi pasar ekspor kembali dilakukan Cadogan di Amerika Serikat dan Inggris. Ada beberapa implikasi dari pentingnya ekspor bagi kelangsungan bisnis. Pertama, bila dibandingkan dengan pasar domestik, beberapa faktor tambahan seperti pengalaman terhadap pasar luar negeri dan ketergantungan terhadap pasar asing akan mempengaruhi kemampuan perusahaan untuk dapat berorientasi pasar.

Kedua, menurut Kohli dan Jaworski, 1990, bila perusahaan melakukan orientasi terhadap pasar domestik sama saja dengan jika 
perusahaan melakukan orientasi terhadap pasar ekspor. Dimana orientasi pasar berkisar kepada perolehan, penyebaran dan aplikasi dari informasi pasar.

Ketiga, tidak adanya bukti empiris mengenai kelayakan orientasi pasar pada organisasi ekspor. Belum ada pengujian mengenai orientasi pasar ekspor dan kinerja bisnis. Perdebatan mengenai hubungan kinerja orientasi pasar ekspor terhadap lingkungan marketing memberikan isi penting bagi pengujian. Tidak ada bukti yang menggambarkan akibat dari lingkungan ekspor pada kekuatan dan hubungan kinerja orientasi pasar.

Ukuran orientasi pasar ekspor memberikan informasi yang bernilai mengenai bagaimana orientasi pasar ekspor berhasil dibandingkan orientasi lainnya. Noting Moorman`s (1995) dalam cadogan, 1999b memberikan komentar kebanyakan organisasi terdiri dari campuran budaya, diharapkan ukuran orientasi pasar ekspor berada pada produk atau pasar yang lebih spesifik untuk memberikan hasil yang lebih potensial.

\section{PEMBAHASAN}

Pada dasarnya terdapat dua tipe faktor internal. Tipe yang pertama adalah yang berkaitan dengan strategi pemasaran ekspor. Pada penelitian ini adalah adaptasi produk, segmentasi pasar, pasar dunia, adaptasi harga, hubungan dalam dan luar negeri dan juga perencanaan ekspor merupakan salah satu didalamnya. Tipe yang kedua adalah yang berkaitan dengan persepsi dan perilaku managerial. Dalam penelitian ini yang menjadi faktor adalah perilaku managerial terhadap konsumen dan kompetitor. Hasil penelitian terhadap faktor internal dapat dilihat pada tabel 3 dibawah

ini.

Tabel 1. Pengaruh Faktor Internal terhadap kinerja ekspor Sumatera Barat

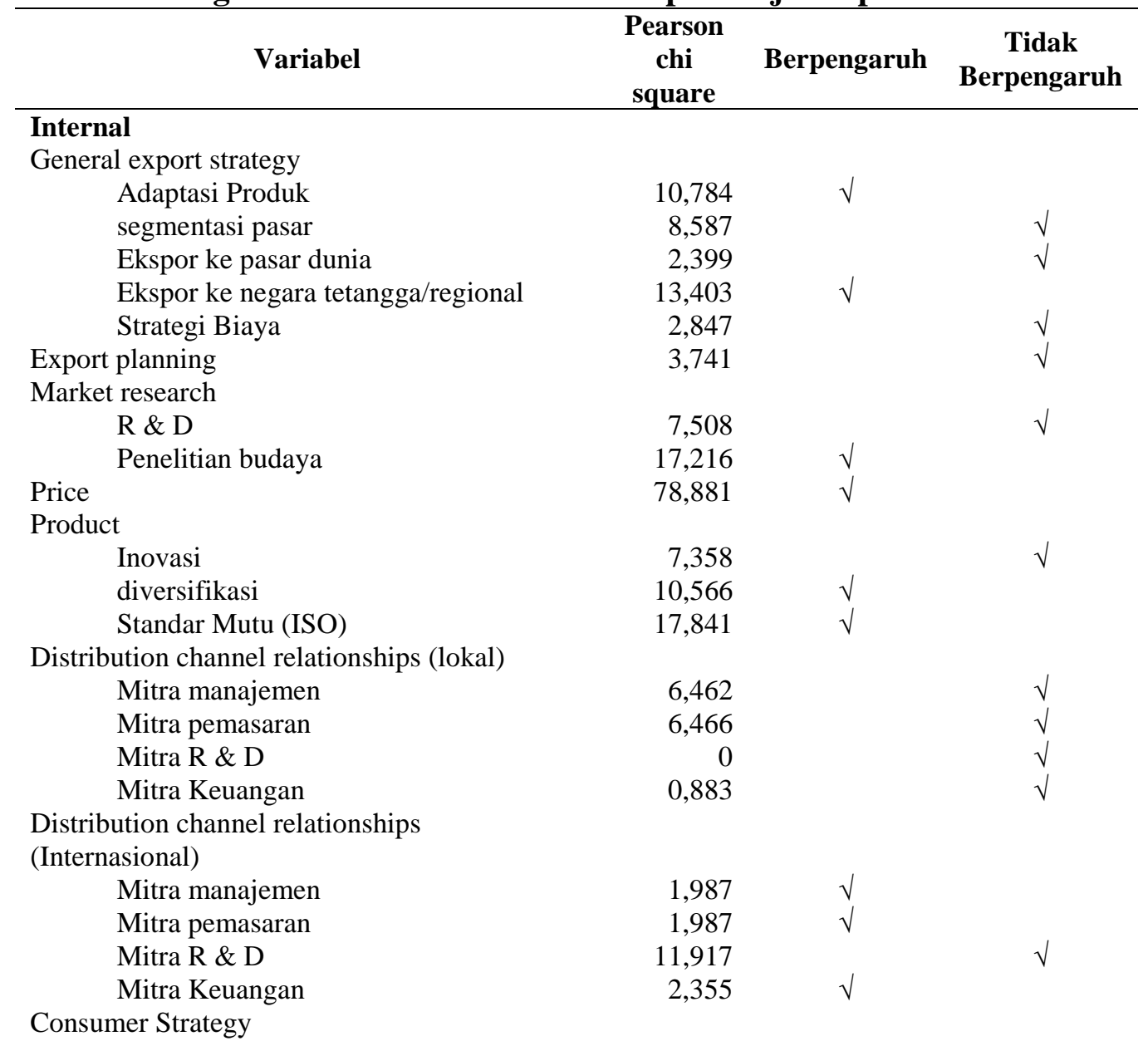




\author{
Sesuai selera dan permintaan konsumen \\ Memantau perubahan selera konsumen \\ Competitor Strategy \\ Informasi kompetitor
}

$\begin{aligned} 23,373 & \sqrt{ } \\ 11,78 & \sqrt{ } \\ 3,864 & \sqrt{ }\end{aligned}$

\section{Sumber: data diolah, survey 2015 \\ General Export Strategy}

Dari hasil uji dapat dianalisis bahwa untuk variabel internal perusahaan yang diwakili oleh indikator strategi ekspor, strategi perusahaan untuk melakukan adaptasi produk berpengaruh positif dan signifikan terhadap kinerja ekspor. Strategi lainnya yang juga mempengaruhi kinerja ekspor adalah strategi perusahaan untuk melakukan ekspor ke negara tetangga. Negara tetangga yang masih berada di wilayah Asia Tenggara. Hal ini ditunjukkan dengan nilai pearson chi square yang lebih besar dibandingkan dengan chi square tabelnya, signifikan pada $\alpha=10 \%$. Penelitian ini sejalan dengan yang ditemukan oleh Ayan, 2005 yang menemukan bahwa adaptasi produk dan strategi ekspor memiliki pengaruh yang positif terhadap kinerja ekspor. Strategi ekspor merupakan variabel yang dapat dikontrol oleh perusahaan ekspor untuk meningkatkan kinerja ekspornya pada saat faktor eksternal tidak dapat dikontrol oleh perusahaan. Sedangkan strategi perusahaan untuk melakukan ekspor ke pasar dunia masih belum dapat mempengaruhi kinerja perusahaan. Perusahaan ekspor di Sumatera Barat masih belum menerapkan sepenuhnya strategi segmentasi pasar. sehingga indikator ini belum bisa mempengaruhi kinerja ekspor. Komoditi yang dijual perusahaan ekspor di Sumatera Barat adalah komoditi primer yang tidak memerlukan biaya pengolahan yang tinggi, sehingga perusahaan ekspor merasa tidak terlalu penting menerapkan strategi biaya.

\section{Export Planning}

Untuk faktor internal yang kedua yaitu perencanaan ekspor tidak ditemukan pengaruh terhadap kinerja ekspor. Hal ini dilihat dari nilai pearson chi square yang lebih kecil daripada nilai chi square tabelnya signifikan pada $\alpha=10 \%$. Perusahaan ekspor di Sumatera Barat ratarata tidak memiliki perencanaan dalam melakukan kegiatan ekspor.

\section{Market Research}

Sedangkan untuk penelitian, perusahaan ekspor rata-rata belum mempunyai anggaran dan program R\&D. Hal ini salah satu penyebab kinerja ekspor perusahaan ekspor di Sumatera Barat masih rendah. Sedangkan perusahaan merasa perlu untuk melakukan penelitian budaya ke daerah tujuan ekspor karena berkaitan dengan selera konsumen. Pada poin ini menunjukkan nilai pearson chi square lebih besar dari chi square tabelnya (signifikan pada $\alpha=10 \%$ ) yang berarti terdapat pengaruh antara penelitian budaya terhadap kinerja ekspor sumatera barat. Mengetahui budaya negara tujuan ekspor menjadi penting untuk melakukan ekspor karena budaya menunjukkan perilaku konsumsi masyarakatnya. Penelitian ini sejalan dengan yang ditemukan oleh Vladimirova, 2013 pada studinya pada perusahaan ekspor di Portugal.

\section{Price}

Strategi harga menunjukkan nilai pearson chi square > dari chi square tabelnya (signifikan pada $\alpha=10 \%$ ). Yang berarti strategi harga memiliki pengaruh yang positif dan signifikan terhadap kinerja ekspor Sumatera Barat. Pertanyaan pada kuesioner yang dibangun untuk mewakili variabel adalah strategi adaptasi harga yang diterapkan oleh perusahaan ekspor. Hasil menunjukkan pengaruh yang signifikan terhadap kinerja ekspor sejalan dengan penelitian yang dilakukan oleh Zou, 1998 dan Hammilton 1993. Namun perlu dilakukan penelitian lebih lanjut 
mengenai pengaruh strategi harga terhadap kinerja ekspor karena, harga diperkirakan hanya merupakan strategi untuk meningkatkan keuntungan.

\section{Product}

Untuk variabel produk, yang diwakili dengan indikator inovasi, diversifikasi, dan standar mutu menunjukkan inovasi tidak memiliki pengaruh terhadap kinerja ekspor. Sedangkan untuk diversifikasi produk dan standar mutu (ISO) menunjukkan terdapat pengaruh yang signifikan terhadap kinerja ekspor (signifikan pada $\alpha=10 \%$ ). Hasil ini tidak sejalan dengan penelitian yang dilakukan oleh Zou, 1998 dan Lages, 2000 yang menemukan adanya hubungan dan pengaruh yang positif antara produk dan kinerja ekspor. Hal ini disebabkan karena perusahaan ekspor di Sumatera Barat sendiri masih tidak melakukan inovasi produk. Produk yang diperdagangkan ke pasar internasional adalah barang primer yang tidak melalui proses pengolahan terlebih dahulu. Padahal, bila dilakukan inovasi terhadap barang primer akan menciptakan nilai tambah yang pada akhirnya akan meningkatkan kinerja ekspor.

\section{Distribution channel relationships (lokal dan Internasional)}

Variabel internal yang mempengaruhi kinerja ekspor Sumatera Barat selanjutnya adalah hubungan perusahaan ekspor dengan mitra dalam dan luar negeri. Mitra dibagi menjadi empat mitra, yaitu mitra manajemen, mitra pemasaran, mitra keuangan, dan mitra R\&D. Dari hasil pengolahan data ditemukan bahwa untuk mitra dalam negeri tidak terdapat pengaruh terhadap kinerja ekspor. Ini menandakan masih kurangnya asistensi dari berbagai pihak terkait, seperti pemerintah, lembaga keuangan dan perguruan tinggi untuk meningkatkan kinerja ekspor di Sumatera Barat. Sedangkan mitra luar negeri hanya mitra R\&D yang tidak menunjukkan hubungan terhadap kinerja ekspor (signifikan pada $\alpha=10 \%$ ). Hal ini terkait juga dengan tidak adanya anggaran dan program R\&D perusahaan dalam menunjang kinerja ekspor.

\section{Consumer Strategy}

Untuk variabel strategi terhadap konsumen, dua indikator yang mewakili yaitu produk sudah sesuai dengan selera konsumen dan perusahaan memantau perubahan selera konsumen memiliki nilai pearson chi square yang lebih besar daripada nilai chi square tabelnya (signifikan pada $\alpha=10 \%$ ). Hal ini berarti bahwa consumer strategy memiliki pengaruh yang positif dan signifikan terhadap kinerja ekspor. Pertanyaan yang dibangun pada variabel ini untuk mengetahui apakah perusahaan memantau perubahan selera konsumen dan melakukan tindakan sesuai dengan pemantauan yang dilakukan. Penelitian ini sejalan dengan penelitian Leonidou, 1996 dan Moghadam, 2011 yang menemukan bahwa dengan menggunakan strategi yang berpatokan pada selera konsumen dapat meningkatkan penjualan dan meningkatkan kinerja ekspor.

\section{Competitor Strategy}

Hal yang sama juga ditunjukkan oleh variabel competitor strategy. Variabel ini diwakili oleh indikator perusahaan memiliki informasi mengenai pesaing atau kompetitornya. Kepemilikan informasi mengenai strategi-strategi kompetitor akan memberikan pengaruh terhadap kinerja ekspor (signifikan pada $\alpha=10 \%$ ). Temuan ini sejalan dengan penelitian yang dilakukan Monteira, 2013 yang menemukan perusahaan ekspor yang melakukan strategi berpatokan terhadap kompetitor dengan memberikan kepuasan yang lebih baik dibandingkan dengan kompetitornya memiliki kinerja ekspor yang baik. 


\section{A. Pengaruh Faktor eksternal terhadap Kinerja Ekspor}

Selain faktor internal, faktor eksternal juga memberikan kontribusi bagi kinerja ekspor Sumatera Barat. Faktor eksternal merupakan variabel yang tidak dapat dikontrol oleh perusahaan. Banyak penelitian menunjukkan faktor eksternal tidak memiliki pengaruh terhadap kinerja ekspor. Kemungkinan hal ini disebabkan oleh bervariasinya jenis perusahaan ekspor yang diteliti dan perlu penelitian lebih lanjut terhadap kemungkinan pengaruh tidak langsung dari faktor eksternal terhadap kinerja ekspor. Tabel dibawah ini menunjukkan hasil survey dari faktor eksternal yang diwakili oleh hambatan perusahaan dalam menjalankan ekspor dan regulasi perdagangan internasional.

Tabel 2. Pengaruh Faktor eksternal terhadap kinerja ekspor Sumatera Barat

\begin{tabular}{|c|c|c|c|c|}
\hline & Variabel & $\begin{array}{c}\text { Pearson } \\
\text { chi } \\
\text { square }\end{array}$ & Berpengaruh & $\begin{array}{c}\text { Tidak } \\
\text { Berpengaruh }\end{array}$ \\
\hline \multicolumn{5}{|c|}{ External } \\
\hline \multicolumn{5}{|c|}{ Export market barriers } \\
\hline & Transportasi & 11,2 & $\sqrt{ }$ & \\
\hline & Kondisi keamanan negara tujuan & 2,431 & & $\sqrt{ }$ \\
\hline & Pajak ekspor & 1,037 & & $\sqrt{ }$ \\
\hline & Nilai tukar & 8,522 & & $\sqrt{ }$ \\
\hline & Perbedaan bahasa & 3,949 & & $\sqrt{ }$ \\
\hline & Pengetatan quota oleh negara tujuan & 4,951 & & $\sqrt{ }$ \\
\hline & Tingkat harga dalam dan luar negeri & 10,416 & $\sqrt{ }$ & \\
\hline \multicolumn{5}{|c|}{ Regulation } \\
\hline \multicolumn{5}{|c|}{ Peraturan pemerintah membantu kegiatan } \\
\hline \multirow[t]{7}{*}{ ekspor } & & 22,652 & $\sqrt{ }$ & \\
\hline & pemerintah membantu manajemen usaha & 13,859 & & $\sqrt{ }$ \\
\hline & Pemerintah membantu pemasaran & 7,538 & & $\sqrt{ }$ \\
\hline & Pemerintah membantu penelitian pasar & 20,844 & $\sqrt{ }$ & \\
\hline & Promosi ekspor & 16,103 & $\sqrt{ }$ & \\
\hline & Peningkatan kualitas ekspor & 10,293 & & $\sqrt{ }$ \\
\hline & Memfasilitasi perusahaan dengan mitra & & & \\
\hline \multirow[t]{4}{*}{ usaha } & & 13,759 & $\sqrt{ }$ & \\
\hline & Memberikan pinjaman & 12,83 & $\sqrt{ }$ & \\
\hline & Prosedur birokrasi & 8,131 & & $\sqrt{ }$ \\
\hline & Kondisi politik dan regulasi & 41,572 & $\sqrt{ }$ & \\
\hline
\end{tabular}

Sumber: data diolah, survey 2015

\section{Export Market Barriers}

Faktor eksternal diwakili oleh variabel hambatan ekspor dan regulasi ekspor. Untuk hambatan ekspor dari hasil penelitian yang dilakukan ditemukan bahwa hambatan ekspor yang mempengaruhi kinerja ekspor adalah transportasi dan perbedaan harga dalam dan luar negeri. Hal ini ditunjukkan oleh nilai pearson chi square $>$ dari chi square tabelnya (signifikan pada $\alpha=10 \%$ ).

\section{Regulation}

Ekspor Sumatera Barat masih sangat membutuhkan sentuhan pemerintah. Karena kebanyakan perusahaan merasakan pemerintah tidak memberikan kontribusi yang dapat mendorong ekspor. Ini dapat dilihat dari kebanyakan perusahaan menjawab bahwa regulasi tidak memiliki pengaruh bagi penjualan. Untuk itu hal yang diperlukan oleh masyarakat adalah peran serta pemerintah untuk mendorong ekspor. Salah satunya yang dapat dilakukan adalah dengan menerapkan regulasi yang tepat agar ekspor Sumatera Barat khususnya dapat berkembang. 


\section{B. Pembahasan}

Hasil yang diperoleh dari penelitian ini menunjukkan nilai yang kurang signifikan bila dibandingkan dengan penelitian-penelitian yang dilakukan oleh peneliti lain di negara-negara maju. Keterbatasan dalam penelitian ini adalah sedikitnya jumlah perusahaan ekspor yang terdapat di Sumatera Barat, dimana penulis hanya mendapatkan sebanyak 26 perusahaan untuk dimintai keterangan. Jumlah ini sangat jauh dibandingkan dengan jumlah perusahaan ekspor yang diteliti di negara maju yang mencapai lebih dari seratus perusahaan. Selain itu jenis perusahaan ekspor di Sumatera Barat adalah perusahaan ekspor barang primer yang masuk dalam kategori industri berskala kecil dan menengah.

Selama periode 1983-2014 perdagangan memberikan andil yang cukup besar bagi perekonomian Sumatera Barat. Rata-rata laju pertumbuhan ekspor Sumatera Barat sebesar 3,70\% pertahun. Ini lebih rendah dari rata-rata laju pertumbuhan ekonomi Sumatera Barat sebesar 5.47\% pertahun. Pada tahun 1999 laju pertumbuhan ekspor mengalami pertumbuhan negatif $22,04 \%$. Hal ini tidak terlepas dari kondisi perekonomian dunia terutama keadaan perekonomian negaranegara tujuan ekspor Sumatera Barat seperti Amerika Serikat, Eropa dan Jepang. Bila dilihat dari kontribusinya terhadap perekonomian Sumatera Barat dari tahun 1983-2014, terjadi penuruan. Penurunan ini menandakan lambannya perkembangan produk yang berorientasi ekspor sebagai mesin pertumbuhan ekonomi. Ekonomi yang dicapai selama tahun 1983-2014 lebih banyak digerakkan oleh permintaan dalam negeri. Perlambatan pertumbuhan ekspor juga disebabkan oleh melemahnya permintaan global dan penurunan harga komoditas utama di pasar global yang keduanya tidak dapat dikontrol perusahaan.

$$
\text { Komposisi ekspor sangat }
$$
ditentukan oleh permintaan dunia. Hingga kini komposisi ekspor Sumatera Barat belum banyak mengalami perubahan. Perkembangan ekspor masih mengandalkan beberapa komoditi primer seperti komoditi karet, cassiavera, kopi, yang masih merupakan produk pertanian dan perkebunan yang mendorong perkembangan ekspor dengan cukup pesat. Sedangkan komoditi di luar sektor pertanian yang berperan dalam komposisi ekspor adalah batubara dari sektor pertambangan dan semen dari sektor industri.

Pada tahun 1983 kontribusi karet terhadap nilai ekspor mencapai 40,30\% yang diikuti oleh komoditi primer lainnya seperti cassiavera sebesar $16,03 \%$ dan kopi sebesar 6,39\%. Ditambah dengan komoditi kayu balok yang memberikan kontribusi sebesar 9,70\% dan rotan sebesar 3,79\%. Kedua komoditi ini baru muncul pada tahun 1980-an sebagai komoditi ekspor, namun sudah dapat memberikan kontribusi yang cukup besar bagi total ekspor Sumatera Barat. Dua komoditi terpilih sebagai produk unggulan daerah dari Propinsi Sumatera Barat dari sektor perkebunan, yaitu Kakao dan Karet, masing-masing komoditi memberikan kontribusi terhadap ekspor nasional. Kontribusi ekspor kakao terhadap ekspor nasional mengalami peningkatan yang cukup tajam pada tahun 2011 dibandingkan dari tahun 2013 kontribusinya sebesar $4,67 \%$ meningkat menjadi $9,08 \%$ di tahun 2014, dimana pada tahun tersebut, nilai ekspor nasional untuk komoditi Kakao mengalami penurunan, namun kontribusi ekspor komoditi kakao dari propinsi Sumatera Barat menunjukkan peningkatan. Untuk komoditi karet, walaupun tidak menunjukkan peningkatan yang tajam seperti halnya komoditi Kakao, namun kontribusinya cenderung stabil dari tahun ke tahun, pada tahun 2013 menunjukkan angka sebesar 9,33\% menurun menjadi $8,68 \%$ di tahun 2014 . 
Amerika Serikat merupakan pasar utama produk Sumatera Barat. Permintaan produk Sumatera Barat di pasar Amerika Serikat selalu mengalami peningkatan yang signifikan. Peningkatan ekspor Sumatera barat disebabkan meningkatnya permintaan komoditi karet oleh Amerika Serikat. Kemajuan industri di Amerika Serikat terutama industri yang membutuhkan bahan baku karet telah mendorong permintaan komoditi karet. Banyaknya permintaan dunia sampai saat ini masih belum dapat dipenuhi oleh Sumatera Barat karena terbatasnya persediaan. Pada tahun 1983 sebesar $44,91 \%$ ekspor Sumatera Barat diserap oleh pasar Amerika Serikat yang bernilai 55,78 juta US \$. Sementara Jepang menyerap 1,21\% produk Sumatera Barat. Untuk tahun 1983 sebagian besar lainnya produk dipasarkan ke negara-negara MEE sebesar $24,75 \%$.

Pada saat krisis ekonomi tahun 1999 ekspor Sumatera Barat dengan tujuan Amerika Serikat mengalami penurunan yang sangat tajam. Nilai ekspor yang mampu diperoleh hanya sebesar 7.6 juta US \$. Pada tahun tersebut dominasi Amerika Serikat dan Jepang tidak lagi tampak. Bahkan komposisinya berada di bawah $5 \%$. Amerika Serikat sebesar 3,3\% dan Jepang sebesar $0,7 \%$.

Disamping Amerika Serikat, Masyarakat Ekonomi Eropa juga merupakan negara tujuan ekspor yang potensial bagi Sumatera Barat. Pada tahun 1999 dimana nilai ekspor ke beberapa negara tujuan mengalami penurunan justru nilai ekspor ke MEE mengalami peningkatan. Peningkatan yang cukup berarti terlihat pada negara Belanda yang nilainya mencapai 17,5 juta US \$ sehingga peranannya terhadap total ekspor juga mengalami peningkatan dari $9,85 \%$ pada tahun 1995 menjadi 21,44\% pada tahun 1999.

Negara tujuan ekspor utama Provisi Sumatera Barat di tahun 2014 adalah Amerika Serikat senilai 902,78 US Dolar atau $29,78 \%$ dari total ekspor Sumatera Barat. Negara tujuan ekspor yang kedua terbesar adalah China dan ditempat ketiga adalah Singapura yang masing-masing memiliki nilai ekspor $354,99(11,71 \%)$ juta US Dolar dan 322,04 $(10,62 \%)$ juta US Dolar.

Kedekatan wilayah Sumatera Barat dengan negara-negara ASEAN mengakibatkan mudahnya jalinan hubungan perdagangan. Walaupun negaranegara ASEAN merupakan negara-negara tujuan baru bagi ekspor Sumatera barat namun nilainya terus mengalami peningkatan yang mengakibatkan peranan negara-negara ASEAN semakin penting terhadap nilai ekspor Sumatera Barat. Pada tahun 1999 nilai ekspor Sumatera Barat ke negara ASEAN mengalami peningkatan mencapai 31,6 juta US \$. Ternyata krisis tidak mempengaruhi nilai ekspor Sumatera Barat ke negara-negara ASEAN. Peningkatan nilai ekspor terlihat pada negara Singapura dan Malaysia. Dimana pada tahun 1995 nilai ekspor ke Malaysia sebesar 10,2 juta US \$ meningkat menjadi 12,8 juta US \$. Disamping itu Singapura juga mengalami kenaikan yang cukup tinggi dari 9,8 juta US \$ pada tahun 1995 menjadi 16,3 juta US \$ pada tahun 1999.

menjelaskan

Pengaruh internal dan eksternal kinerjaeksporperusahaansebagaisalahsatu unit bisnispribadi. Meskipun analisis yang disajikan dalam penelitian ini sangat sederhana, namun telah dapat menjelaskan sebagian dari kegiatan ekspor perusahaan di Sumatera Barat. Hasil yang didapatkan menunjukkan bahwa model ini dapat digunakan di Sumatera Barat maupun Indonesia yang rata-rata perusahaannya bergerak dalam ekspor barang primer. Kebanyakan eksportir barang primer di Sumatera barat tidak menunjukkan memiliki strategi pemasaran yang berorientasi dunia.

Meskipun untuk mengekspor barang primer tidak membutuhkan adanya 
perkembangan produk yang mengkibatkan tingginya tingkat persaingan, namun ternyata faktor internal dapat dipakai untuk mengukur kinerja ekspor perusahaan. Salah satu penyebab dapat dipakainya ukuran ini adalah karena adanya kemajuan teknologi yang mengakibatkan barangbarang primerpun mengalami perbaikan kualitas. Tingkat persaingan barang bukan olahanpun menjadi tinggi.

Sumatera Barat merupakan propinsi yang mengandalkan ekspor barang primer sebagai faktor penggerak perdagangan luar negerinya. Kelemahan Sumatera Barat untuk bersaing dengan negara-negara lainnya antara lain karena eksportir Sumatera Barat tidak memiliki perencanaan ekspor dan menerapkan strategi managerial. Kegiatan ekspor yang dilakukan perusahaan semata-mata karena adanya peluang pasar. Peluang pasar tersebut bukanlah karena diciptakan sendiri oleh perusahaan sebagai sebuah unit bisnis, namun karena adanya dorongan permintaan dari luar negeri. Pada saat permintaan pasar dunia melemah maka perusahaan ekspor cepat merasakan imbasnya langsung.

Dari hasil penelitian lapangan menunjukkan bahwa perusahaan yang tidak memiliki strategi tidak dapat bertahan menghadapi tingkat persaingan luar negeri. Beberapa perusahaan menghentikan kegiatan ekspornya karena tidak adanya lagi permintaan dari negara tujuan ekspor. Penyebabnya antara lain yang diakui perusahaan adalah adanya kompetitor yang dapat memberikan produk yang lebih baik. Hal ini mengakibatkan importir mengalihkan pembeliannya ke eksportir lain dengan komoditi yang sama. Selain itu penyebab lainnya adalah adanya perubahan regulasi dari negara tujuan ekspor yang tidak dapat diantisipasi oleh eksportir Sumatera Barat.

Hasil analisis menyimpulkan dengan adanya aktifitas yang besar kepada strategi pemasaran, konsumen, kompetitor, kondisi politik dan regulasi dapat berpengaruh positif terhadap kinerja ekspor. Hal ini mengindikasikan bahwa dalam era perdagangan bebas tingkat persaingan mengalami kenaikan yang cukup signifikan. Keadaan ini bila tidak ditanggapi secara serius akan mengakibatkan produk ekspor kita kalah bersaing di pasar internasional.

\section{PENUTUP}

Dari hasil penelitian dapat disimpulkan bahwa perusahaan ekspor di Sumatera Barat masih didominasi oleh perusahaan produk primer. Negara tujuan ekspor juga masih didominasi oleh Amerika Serikat dan diikuti oleh negara-negara MEE. Hasil penelitian menunjukkan masih banyaknya faktor internal yang tidak memiliki pengaruh terhadap kinerja ekspor, hal ini berlawanan dari penelitian sebelumnya yang sudah dilakukan di negara-negara maju terhadap perusahaan ekspor yang tergolong dalam industri besar. Namun begitu, hasil analisis ini sudah dapat menunjukkan perilaku perusahaan ekspor sebagai unit bisnis pribadi. Dari hasil penelitian, maka dapat disimpulkan:

1. Faktor internal perusahaan yang berkaitan dengan strategi pemasaran ekspor seperti adaptasi produk, segmentasi pasar, pasar dunia, adaptasi harga, hubungan dalam dan luar negeri dan juga perencanaan ekspor dan yang berkaitan dengan perilaku managerial terhadap konsumen dan kompetitor menunjukkan hubungan dan pengaruh yang positif terhadap kinerja ekspor. Mempertimbangkan faktor internal perusahaan sebagai variabel yang dapat dikontrol dapat meningkatkan kinerja ekspor.

2. Faktor eksternal perusahaan yang mencakup hambatan ekspor dan regulasi menunjukkan hubungan dan pengaruh yang positif terhadap kinerja ekspor. Dari faktor eksternal menunjukkan bahwa perusahaan ekspor Sumatera Barat sudah mulai mencapai advanced phase dimana perusahaan 
sudah dapat mengatasi beberapa hambatan ekspor.

Bertitik tolak dari hasil penemuan empiris sebelumnya dan hasil penemuan empiris dari studi ini, maka penulis mengemukakan saran-saran sebagai berikut :

1. Perusahaan ekspor untuk meningkatkan kinerja ekspornya dapat menggunakan berbagai strategi dan meningkatkan penelitian terhadap produk, konsumen dan kompetitornya. Kondisi perekonomian Indonesia saat ini memang masih tidak stabil, ditandai dengan terus berfluktuasinya nilai Rupiah terhadap Dollar Amerika Serikat. Untuk terus dapat bersaing dengan produk luar negeri, dunia usaha, khususnya di Sumatera Barat hendaknya memiliki strategi khusus. Salah satunya dengan memperkuat sektor internal yang akan memberikan nilai tambah bagi suatu produk itu untuk bersaing dengan poduk lain.

2. Pemerintah sebagai aktor yang berperan dalam faktor eksternal hendaknya terus melakukan upaya untuk menjaga kestabilan politik dan membantu perusahaan dalam usahanya meningkatkan kinerja ekspor melalui regulasi dan informasi untuk perusahaan ekspor di Sumatera Barat

3. Untuk penelitian selanjutnya dapat menambah jumlah sampel dengan memperluas daerah penelitian.

\section{DAFTAR PUSTAKA}

\section{$\underline{\text { 10.22202/economica.2016.v4.i2.632 }}$}

Acs, Zoltan J, (2001). Entrepreneurship, Globalization and Public Policy, journal of International Management, Vol 7 (2001), 235251

Arthur, Baldauf, David W. Cravens, Udo Wagner, (2000). Faktor yang Menentukan Performansi Ekspor dalam Perekonomian Terbuka, Journal of World Business 135(1)

Ayan, Tuba Yakici and Selcuk Percin (2005). A Structural Analysis of the Determinants of Export Performance: Evidence from Turkey. Innovative Marketing, Volume 1, Issue 2

Bughin, Jacques, (1996). Capacity Constraints and Export Performance: Theory and Evidence from Belgian manufacturing, The Journal of Industrial economics, Vol. XIIV No.2, 187-204

Cadogan (1999a), John W, Adamantious Diamantopoulus, \& Charles D. Pahud De Mortages, A measure of Export market Orientation: Scale Development and Cross Cultural Validation, Journal of International Business Studies Vol. 30, No. 4, 689-707

Cadogan, (1999b), Export Market Behaviour, Its Antecendents, Performance Consequences, and Moderating factors: Evidence from US and the UK, www.absaston.ac.uk

Cooper, Robert G, Elko J. Kleinschmidt (2001), The Impact of Export Strategy on Export Sales Performance

Dicht, Erwin, Hans-George Keglmayr \& Stefan Mueller (1990). International Orientation as a Precondition for Export Success, Journal of International Business Studies Vol 21, Issue 1, 23-40

Edwards, Sebastian (1997). Trade Policy, Growth and Income Distribution, The American Economic Review, Vol. 87, Issue 2, 205-210

Engel, James F (1994). $\underline{\text { Perilaku }}$ Konsumen, Binarupa Aksara : Jakarta

Gomez, Louis R (1998). The Role of Human Resources Strategy in Export Performance: A Longitudinal Study, Strategis Management Journal, Vol. 9, 493505 
Gujarati, Damodar (2000). Ekonometrika Dasar, PT. Gelora Aksara Pratama: Jakarta

Heiens, Richard A (2000). Market Orientation: Toward an Integration Framework, http:/www.Amsreview.org/articles/ heins01-2000.pdf

Karimi, Syafruddin (2001). Perekonomian Makro dan Perdagangan Internasional Sumatera Barat, Disampaikan dalam Seminar Peran Perbankan dalam Perekonomian Sumatera Menghadapi Globalisasi, Padang 31 Desember 2002

Kumcu, Erdogan, Talha Harcar, M. Ecan Kumcu (1995). Managerial perception of The Adequacy of Export Incentive Program: Implications for Export-Led Economics Development Policy, Economic Development Policy Journal of Business Research, 32:163-174

Lages,Luis Filipe and T C Melewar (1999). Determinants Of Export Performance And Moderating Effects Of Marketing Programme Adaptation:A Review, Conceptual Framework And Research Hypotheses. Warwick Business School No. 317

Lee, Woo-Young, John J. Brasch (1978).

The Adoption of Export as Innovative Strategy, Journal of International Business Studies, Vol. 9, Issue 1, 85-93

Leonidou, Leonidas C \& Constantine S. Katsikeas (1996). The Export Development Process: An integrative Review of Empirical Models, Journal of International Business Studies, Third Quarter, 517-551

Moghaddam, farshidMovaghar, et all (2012). The Influence of Export Marketing Strategy Determinants on Firm Export Performance: A Review of Empirical literatures
Between 1993-2010. IJFPSSVol. 1 No. 2

Mohammad dan Osman, herri (2001). Memasuki Pasar Ekspor: Perbedaan antara Eksportir Sistematik dan Tidak Sistematik, Jurnal Strategi Bisnis, Vol 6/Thn. IV, 26-34

Monteiro, Tatiana Maria Correia (2013). Relationship Between Firm Size And Export Performance: Overtaking Inconsistencies (Disertation). FEP

Mudie, Peter (1997). Marketing: An Analytical Perspective, Prentice hall : Europe

Salvatore, Dominick (2006). Ekonomi Internasional, Erlangga : Jakarta

Schlegelmilch, B.B. \& J.N. Crook (1978). Firm Level Determinants of Export Intensity, Managerial and Decision Economics, Vol. 9, Issue 1, 47-58

Westpdhal, Larry E, (1990). Industrial Policy on Export Propeled Economy: Lessons from South Korea's Experience, The Journal of Economic Perspective, Vol. 4, Issue 3, 41-59

Wild John J, Kenneth L. Wild, Jerry C.Y Han (2000). International Business: An Integrated Approach, Prentice Hall : New Jersey

Zou, Shaoming and Simona Stan (1998). The determinants of export performance: a review of the empirical literature between 1987 and 1997. International Marketing Review, Vol. 15 No. 5 (333-356) 